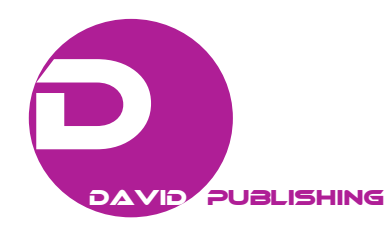

\title{
BIM Implementation-A Bibliographic Study of the Benefits and Costs Involved
}

Livia Haraguchi ${ }^{1}$, Patricia Stella Pucharelli Fontanini ${ }^{2}$, Ana Elisabete Paganelli Guimarães de Ávila Jacintho ${ }^{1}$ and Lia Lorena Pimentel ${ }^{1}$

1. School of Civil Engineering, PUCCAMP (Pontifical Catholic University of Campinas), Campinas 13083-889, Brazil

2. School of Civil Engineering, UNICAMP (University of Campinas), Campinas 13086-900, Brazil

\begin{abstract}
The construction sector has always been constantly changing, becoming increasingly aggressive, requiring new strategies to adapt to international and national scenarios. In the development of a project, there are many constraints, which often end up in problems such as waste materials, generating waste affecting the environment and also resulting in high costs of the work that could be avoided. Then came the concept of BIM (building information modeling) defined by a digital model consists of a database, allowing the development of projects with various professionals working in an integrated manner, being able to support all aspects of the life cycle of the project. Therefore, from the research information on the implementation of BIM methodology, it was possible to propose new ways of thinking and designing buildings, contributing to the completion of research in the management of projects and sustainability areas relevant to the development of engineering.
\end{abstract}

Key words: Building information modeling, civil construction.

\section{Introduction}

The construction industry has always been in constant change. As technology advances, building projects that were previously done manually, began designed in CAD (computer aided design) tools. Despite improvements in the process and practicality, the application also has an inefficient system of management of information and communication exchange processes, generating conflicts, rework and waste [1].

In the development of a project in a civil construction, they are involved many constraints, such as information on specifications for materials, labor cost and runtime, which must be managed simultaneously in the planning and execution process [2].

In the process, professionals from different areas, work in separate rooms and intensive use of information. According to Dawood [3], in most of

Corresponding author: Patricia Stella Pucharelli Fontanini, professor, research fields: lean construction, simulation, BIM, kanbim and material flow. cases, the lack of cooperation between those involved in the work, causes a lack of efficiency and productivity. Therefore, the success to develop the building design depends upon the compatibility of different information elements involved.

Therefore, the concept of BIM-building information modeling has emerged, which according to Eastman [4] is a digital model, made up of a database that allows the development of projects with several professionals working in an integrated way. When associated with durations of activities or stages of construction, the model can be used by viewing the execution of the work plan for design and production planning systems for construction projects [5].

The BIM model introduces 4D modelling, bringing benefits such as the fact that they have not only the geometrical building information, but also information concerning the production process, such as productivity rates, cost and type of resources needed. Also, the changes that are made in the $3 \mathrm{D}$ model can be automatically updated in the 4D model, making it possible for planners, the creation, review and editing 
of models more often, enabling models and the performance in the construction sequence evaluation [4].

The BIM application within the engineering and architecture colleges allows the detailing and the integration of building elements and their spatial relationships, analyzing the sequence of activities that will be needed for the construction of the project, understanding the importance of a collaborative project and best sequence of operations that are carried out by various professionals in the work [6], bringing significant changes to the design process.

Thus, in projects, the main reasons for the adoption of BIM are:

- improving project quality;

- reducing errors;

- designing modification facility;

- reducing the delivery time.

Despite the various uses of BIM in Brazil, the country is still limited to architectural design offices, still being used in a way that the project activity occurs in isolation [7].

The BIM implementation presupposes the restructuring of companies through the reorganization of processes and a new way of organizing work and a new way of thinking of the design process in an integrated manner. However, some factors hinder the effective deployment of technology in project offices in Brazil, as the shortage of skilled labor, the resistance to change and the high investment in machinery and training. Therefore, the domestic industry needs to follow global developments, seeking adjustments in BIM technology to the country's profile in order to facilitate its implementation on a large scale, seeking the modernization of construction processes.

From this research, it was possible to investigate international case studies, bringing the main focus, the benefits of adopting the BIM process to encourage its use in Brazil.

\section{BIM Applications in the Project Cycle}

\subsection{D Simulation}

Through the BIM 3D view, it is possible that an early identification of project conflicts, called clash detection, avoiding mistakes and rework to the project. There is also a freedom to manipulate the object within the design, thereby enabling the visualization of the detailed model constructed.

\section{$2.24 D$ Schedule}

4D models consist of a combination of digital geometric model of the development and the information coming from the planning of its construction [8-10], including project analysis in the time sequence according to the construction schedule. Therefore, it is possible that the visualization and communication, integration agents, logistics study, support coordination and monitoring of planning [4], generating an association between the levels of detail schedule and components from the 3D model.

\section{$2.35 \mathrm{D}$ Costs}

The cost management in a building is essential for a project. In BIM 5D model, it is added the budget to the $3 \mathrm{D}$ model of the project, providing a single source for the cost of all the work cycle, thereby improving the management and planning of the project.

\subsection{D Maintenance and Operation Control}

With BIM 6D, the complete management of the development life cycle is possible, called facilities management, including details of the components of the work and maintenance. When this data is linked to the information model, the $6 \mathrm{D}$ assists in a decision making during the process and operation of the building.

\section{Methodology}

For the development of the article, international 
bibliographic data of case studies were collected [11], aiming to seek investment value in BIM, the adopted software and the benefits to the company. Then, Table 1 was developed gathering all the information and for an analysis, it was inserted a chart with the percentage of the improvements achieved by BIM. Finally, the article ended with a flowchart proposing the initial basic costs of a simple implementation of the BIM process for a company of medium-size in Brazil.

\section{Case Studies in BIM Applicability}

From a bibliographic review of international case studies, a table was drawn up, gathering information on investment value in BIM, the improvements of the companies after the implementation process and the software used.

\subsection{Comparative Case Studies}

Unlike traditional CADs models in the BIM process, there are assigned information to the 3D design model, where users combine interactively model with a business plan, getting a preview of the work execution plan to design and plan. This model is shared by a project team, working together, where each employee

Table 1 Case studies analyzed.

\begin{tabular}{|c|c|c|c|c|}
\hline Local & Company & Investment & Implementation improvements with BIM & Software used \\
\hline London, England & KSS Group & $€ 500,000$ & $\begin{array}{l}\text { Prediction; } \\
\text { Reducing deadline }\end{array}$ & \begin{tabular}{|l|} 
Autodesk \\
Building Design \\
Suite \\
\end{tabular} \\
\hline Swindon, England & NC Architects & $€ 60,000$ & $\begin{array}{l}\text { 3D visualization; } \\
\text { Reducing deadline; } \\
\text { Reducing rework } \\
\end{array}$ & $\begin{array}{l}\text { Revit; } \\
\text { RevitStructures }\end{array}$ \\
\hline Hereford, England & Architype & $€ 70,000$ & $\begin{array}{l}\text { 3D visualization; } \\
\text { Speed in the documentation; } \\
\text { Professionals working in an integrated way }\end{array}$ & $\begin{array}{l}\text { Revit; } \\
\text { Vectorworks; } \\
\text { Ecotect } \\
\end{array}$ \\
\hline London, England & David Miller Architects & $€ 30,000$ & $\begin{array}{l}\text { Improvement in productivity; } \\
\text { Professionals working in an integrated way; } \\
\text { 3D visualization }\end{array}$ & Revit \\
\hline $\begin{array}{l}\text { Sheffield, Belfast, } \\
\text { Cardiff, Glasgow, } \\
\text { London, Plymouth, } \\
\text { Johannesburg, Pretoria, } \\
\text { Abu Dhabi }\end{array}$ & HLM & $€ 200.000$ & $\begin{array}{l}\text { Professionals working in an integrated way; } \\
\text { 3D visualization; } \\
\text { Fast learning process }\end{array}$ & ArchiCAD \\
\hline \begin{tabular}{|l|} 
London, Birmingham, \\
Cardiff, England \\
\end{tabular} & Capita Symonds & $€ 250,000$ & $\begin{array}{l}\text { Project review; } \\
\text { Environmental sector monitored }\end{array}$ & Revit \\
\hline Birmingham, England & Axis Design & $€ 15,000$ & $\begin{array}{l}\text { 3D visualization; } \\
\text { Improvement in the quality of the project; } \\
\text { Speed in the documentation }\end{array}$ & ArchiCAD \\
\hline London, England & Emily Greeves Architects & $€ 2,200$ & $\begin{array}{l}\text { Speed in the documentation; } \\
\text { Fast learning process; } \\
\text { Professionals working in an integrated way; } \\
\text { Efficiency }\end{array}$ & ArchiCAD \\
\hline Anglesey, Wales & $\begin{array}{l}\text { WM Design \& } \\
\text { Architecture }\end{array}$ & $\begin{array}{l}€ 10,000 \sim \\
€ 12,000\end{array}$ & $\begin{array}{l}\text { Reducing errors; } \\
\text { 3D visualization; } \\
\text { Fast learning process; } \\
\text { Generation of a schedule }\end{array}$ & ArchiCAD \\
\hline $\begin{array}{l}\text { Atlanta, Georgia, } \\
\text { USA }\end{array}$ & $\begin{array}{l}\text { Holder Construction } \\
\text { Company; } \\
\text { Aquarium Hilton Garden } \\
\text { Inn }\end{array}$ & $\$ 90,000$ & $\begin{array}{l}\text { Cost reduction; } \\
\text { Professionals working in an integrated way }\end{array}$ & Others \\
\hline $\begin{array}{l}\text { Savannah, Georgia, } \\
\text { USA }\end{array}$ & $\begin{array}{l}\text { Holder Construction } \\
\text { Company; } \\
\text { Savannah State University }\end{array}$ & $\$ 5,000$ & $\begin{array}{l}\text { Reducing errors; } \\
\text { Better decision making }\end{array}$ & Others \\
\hline $\begin{array}{l}\text { Atlanta, Georgia, } \\
\text { USA }\end{array}$ & $\begin{array}{l}\text { Holder Construction } \\
\text { Company; } \\
\text { The Mansion on Peachtree }\end{array}$ & $\$ 1,440$ & $\begin{array}{l}\text { Cost reduction; } \\
\text { Best project planning and coordination; } \\
\text { Construction documentation }\end{array}$ & Others \\
\hline
\end{tabular}


contributes to your local desktop and updates a central database. About $17 \%$ of cases (Fig. 1) found that there was a significant increase in productivity by adopting software using BIM, a good 3D representation being possible in less time compared to CADs programs. Finally, with increasing design office productivity, the term reduction is possible, thereby occurring a reduction in costs.

Thus, BIM benefits a project to share a single, integrated digital model, being able to support all aspects of the life cycle in the construction project, mainly through collaboration and simulation, generating increased productivity, reduced costs and term [12].

From the survey data on the choice of software BIM each company adopted (Fig. 2), it was found that Revit and ArchiCAD are the most used, with a draw around $29 \%$. The intuitive interface of the program is the main motivation of companies to adopt such software with a fast and effective learning for professionals involved in the projects.

Through the investment percentage chart of companies in BIM (Fig. 3), it was observed that the cost for the implementation for the most part, was less than $€ 50,000$. Thus, it did not take a big investment to get the benefits of the process.

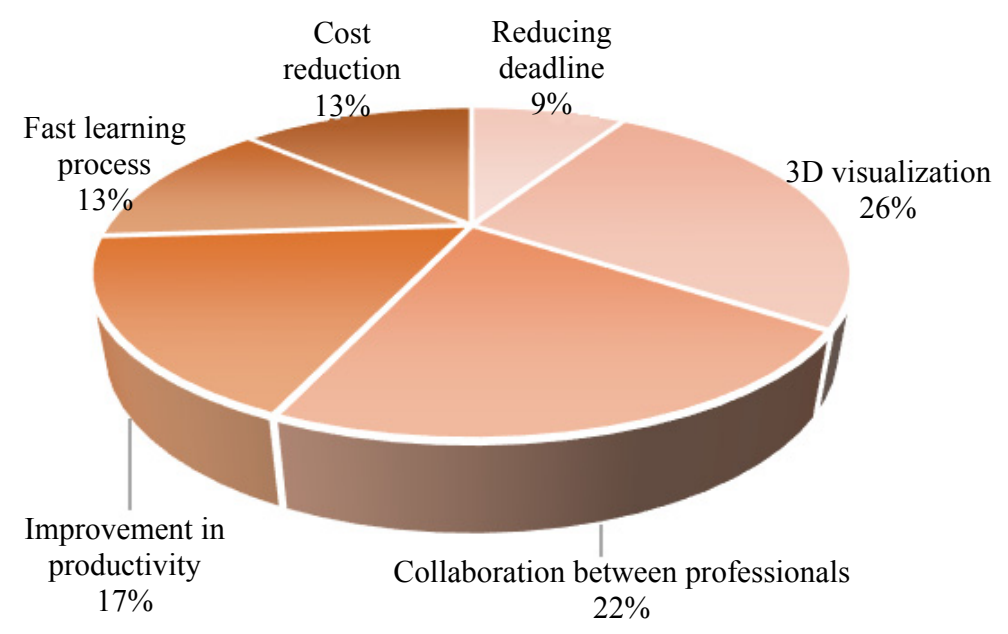

Fig. 1 Percentage of improvements achieved through BIM implementation.

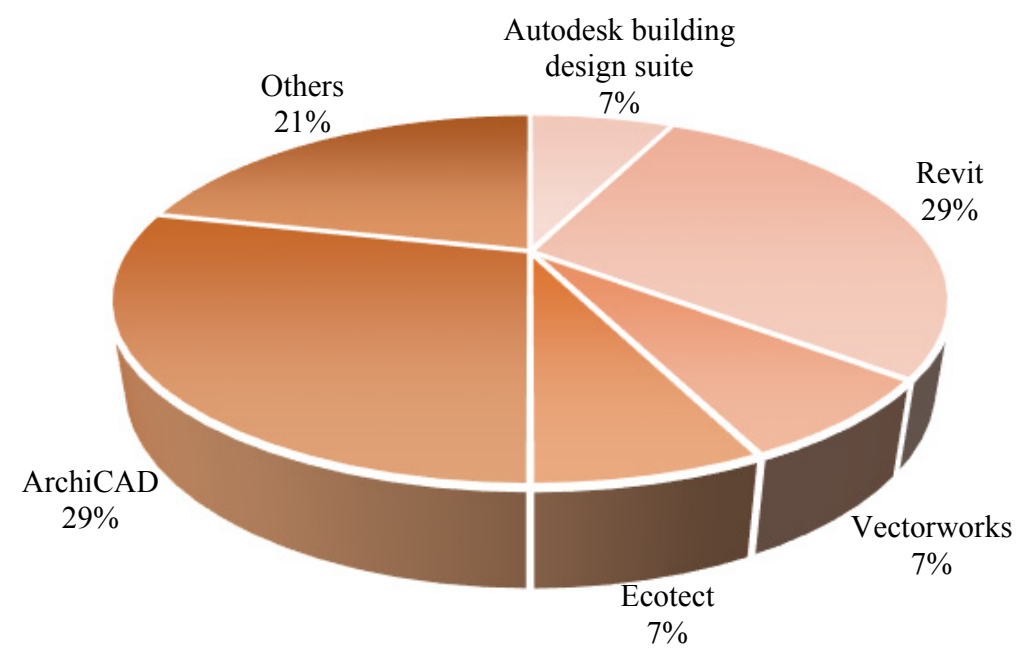

Fig. 2 Percentage referring to the preference of companies in selecting a software for the BIM implementation. 


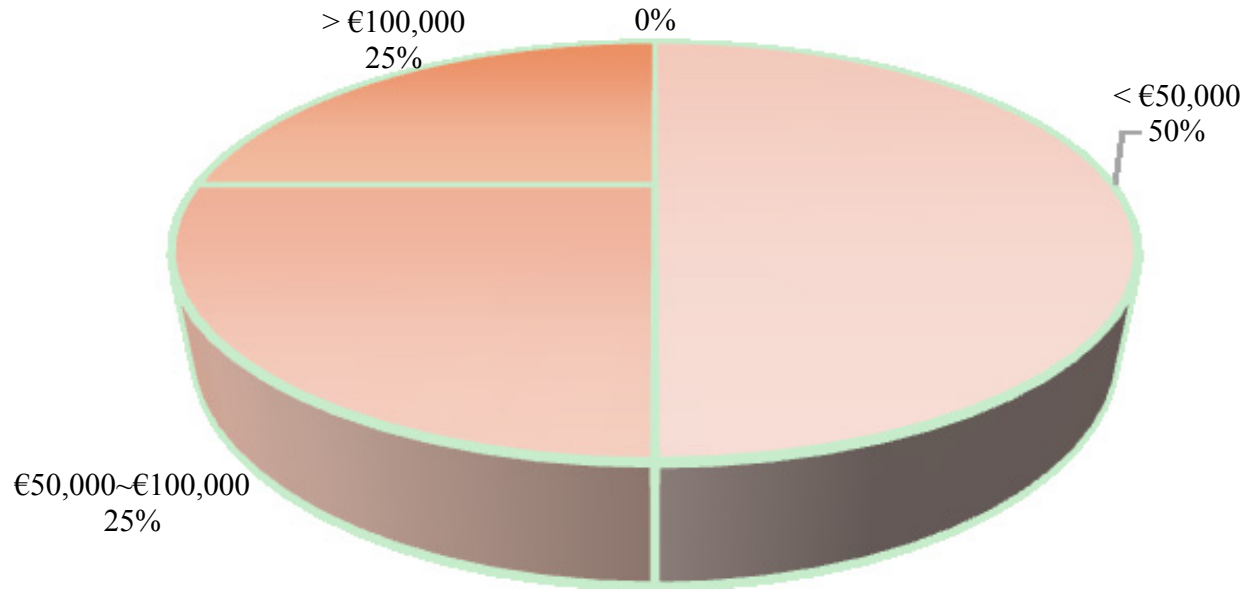

Fig. 3 Investment percentage of companies in BIM implementation.

\section{Cost/time for the implementation of BIM}

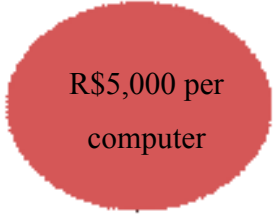

Suitable computer

requirements for

use of BIM

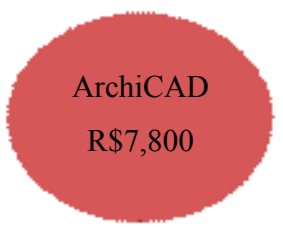

Software license

BIM
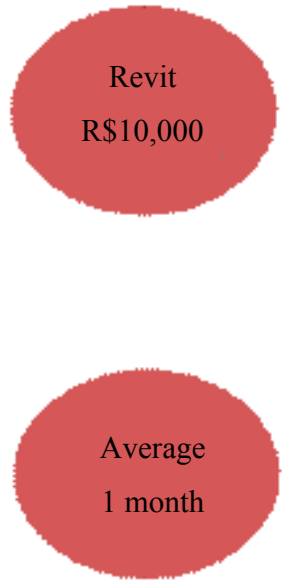

Integration of professionals

Average 6 8 months
Architecture/structure

/hydraulic/electric
$\mathrm{R} \$ 2,000$ per

professional $40 \mathrm{~h}$

Basic training on

BIM concept

Fig. 4 Flowchart cost for a basic BIM implementation in Brazil.

$\mathrm{R} \$ 1,500$ per

professional $40 \mathrm{~h}$ 


\section{BIM Implementation in Brazil}

The market in the construction sector is highly competitive, with frequent technological changes. For the development of Brazil, it is important that the country accompanies these innovations, thus boosting productivity and economy in civil engineering. From a bibliographical research [13], it was assembling a flowchart with the cost for a basic implementation of the BIM process using Revit software in Brazil (Fig. 4).

According to Lourencon [13], the use of software with BIM technology requires powerful computers with an extended memory because the amount of generated files are usually large in size. Thus, it is important that each computer has minimum specifications for proper use of the process. The cost for a machine with such requirements is an average of $\mathrm{R} \$ 5,000.00$. In addition, a license is required to work with the software Revit, with an average cost of $\mathrm{R} \$ 10,000.00$ and ArchiCAD about $\mathrm{R} \$ 7,800.00$.

For the implementation of BIM, business restructuring is assumed through the reorganization of processes and a new way of organizing work and thinking of the design process in an integrated manner. For the success of this change, there are important basic training on BIM concept and the software itself, ensuring perfect functionality and execution of the process. However, there is a period of adjustment for professionals to meet a new change, estimated $6 \sim 8$ months.

\section{Conclusions}

From the research, it was possible to collect data of the main benefits by adopting BIM and its implementation cost in foreign companies. And it is verified that, considering the numerous benefits that the process has brought to the project, the cost is low. Also, from a flowchart, it has raised the costs for a basic BIM integration in Brazil.

It can be concluded that the BIM process goes through a time of group validation, reducing compatibility problems of architectural projects and complementary disciplines, with a new way to represent the virtual building where digital objects are coded to describe and represent components' actual cycle construction of life, contributing to the improvement in the development and planning of a project and essential use in the construction sector in Brazil.

\section{References}

[1] Ruschel, R. C. 2013. "O Papel das Ferramentas BIM de Integração e Compartilhamento no Processo de Projeto na Indústria da Construção Civil." REEC (Revista Eletrônica de Engenharia Civil, Goiânia) 7 (3): 36-54. (in Portuguese)

[2] Formoso, C. T., and Ino, A. 2003. Inovação, Gestão da Qualidade \& Produtividade e Disseminação do Conhecimento na Construção Habitacional. Vol. 2. Porto Alegre: Coletânea Habitare. (in Portuguese)

[3] Dawood, N., Sriprasert, E., Mallasi, Z., and Honns, B. 2002. "4D Visualization Development: Real Life Case Studies." Presented at 2002 International Council for Research and Innovation in Building and Construction, CIB W78 Conference, Aarhus, Denmark.

[4] Eastman, C., Teicholz, P., Sacks, R., and Liston, K. 2008. BIM Handbook: A Guide to Building Information Modeling for Owners, Managers, Designers, Engineers, and Contractors. Hoboken, New Jersey: John Wiley \& Sons.

[5] Biotto, C. N., Formoso, C. T., and Isatto, E. L. 2015. "Uso de Modelagem 4D e Building Information Modeling na Gestão de Sistemas de Produção em Empreendimentos de Construção." Ambiente Construído 15: 79-96. (in Portuguese)

[6] Florio, W. 2007. "Contribuições do Building Information Modeling no Processo de Projeto em Arquitetura." Presented at 2007 Seminário TIC (Tecnologia da Informação e Comunicação) na Construção Civil, Porto Alegre, Brazil. (in Portuguese)

[7] Andrade, M., and Ruschel, R. 2009. "Interoperabilidade Entre Archicad e Revit Por Meio do Formato IFC." Presented at 4th Encontro de Tecnologia de Informação e Comunicação na Construção Civil, Rio De Janeiro, Brazil. (in Portuguese)

[8] Kunz, J., and Fisher, M. 2011. "Virtual Design and Construction: Themes, Case Studies and Implementation Suggestions." CIFE working paper \#097, Stanford University. 
[9] Riley, D. 2005. "The Role of 4D Modeling in Trade Sequencing and Production Planning." In $4 D C A D$ and Visualization in Construction: Developments and Applications, edited by Issa, R. R., Flood, I., and O'Brien, W. J. Lisse/Abingon/Exton, PA: A. A. Balkema Publishers.

[10] Rischmoller, L., and Alarcón, L. F. 2002. "4D-PS: Putting an IT New Work Process into Effect." In Internacional Conference $C I B \quad$ W78, Arhus: Distributing Knowledge in Building.
[11] Building Design. 2011. Investing in BIM: A Guide for Architects. White papers 01: BIM.

[12] Crespo, C., and Ruschel, R. 2007. "Ferramenta BIM: Um Desafio para a Melhoria no Ciclo de Vida do Projeto." Presented at 3rd Encontro de Tecnologia de Informação e Comunicação na Construção Civil, Porto Alegre, Brazil. (in Portuguese)

[13] Lourençon, A. C. 2011. "Quanto Custa Implementar o BIM." AU (Arquitetura e Urbanismo) 208: 76-7. (in Portuguese) 